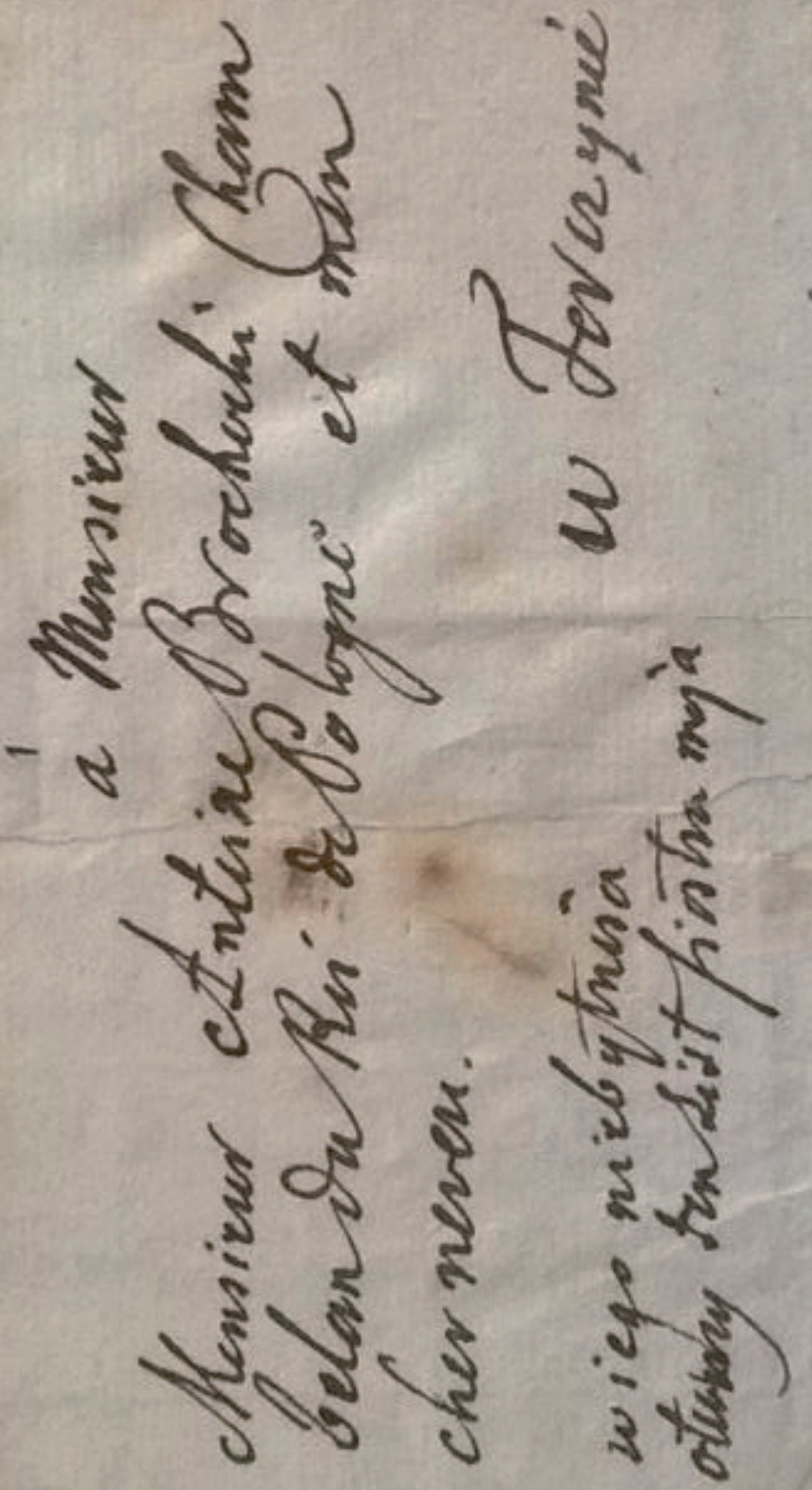


Sztuka Edycji 2/2018

ISSN 2084-7963 (print)

ISSN 2391-7903 (online)

s. $113-129$

\section{Nieznana korespondencja Adama Naruszewicza}

\author{
(opracowanie edytorskie Magdalena Bober-Jankowska)
}

Biblioteka Czartoryskich w Krakowie, Biblioteka Jagiellońska, Biblioteka

Baworowskich we Lwowie, Biblioteka Zakładu Narodowego im. Ossolińskich, Archiwum Główne Akt Dawnych w Warszawie, Archiwum Diecezjalne w Płocku to tylko kilka instytucji, w których są przechowywane listy Adama Naruszewicza. Julian Platt, wydając w 1959 roku tom korespondencji autora Historii narodu polskiego, wskazał znacznie więcej takich miejsc ${ }^{1}$. Mimo licznych kwerend przeprowadzonych w bibliotekach i archiwach oraz pokaźnego, liczącego blisko pół tysiąca zespołu zgromadzonych listów, gdańskiemu badaczowi nieustannie towarzyszyła świadomość niekompletności przygotowanej edycji ${ }^{2}$. Wydaje się, że jej przyczyną było przede wszystkim rozproszenie listów, zwykle w takich przypadkach stanowiące największe wyzwanie dla wydawcy.

Julian Platt zmierzył się z nim, przygotowując doskonałą edycję, z której badacze i znawcy twórczości Adama Naruszewicza korzystają na co dzień w swojej pracy. Nie mylił się jednak, gdy podkreślając dążenie do oddania w ręce czytelników „najbardziej kompletnego zespołu korespondencji Adama Naruszewicza”, dostrzegał zarazem konieczność kontynuacji poszukiwań. Zostały one podjęte blisko sześćdziesiąt lat po ukazaniu się Korespondencji Adama Naruszewicza i zaowocowały odnalezieniem siedmiu autografów niepublikowanych listów biskupa łuckiego.

Korespondencja odkryta w Archiwum Głównym Akt Dawnych w Warszawie obejmuje sześć listów i znajduje się w dwóch różnych zespołach archiwalnych. Pierwszy z nich to Zbiór Muzeum Narodowego, w którym zachowały się pisma do Antoniego Brochockiego, Kazimierza Naruszewicza oraz Mierzejewskiego. W dru-

J. Platt, Od wydawcy, w: Korespondencja Adama Naruszewicza 1762-1796, z papierów po L. Bernackim uzupetnił, opracował i wydał J. Platt, pod red. T. Mikulskiego, Wrocław 1959, s. VIII-XII.

${ }^{2}$ Ibidem, s. XII.

${ }^{3}$ lbidem. 
gim zespole archiwaliów, czyli Zbiorze Michała Marczaka, pomieszczono jeden list adresowany do Stanisława Augusta. Ostatni z odnalezionych rękopisów skrywały dotychczas mury Archiwum Zamku Królewskiego - Muzeum. W zbiorze korespondencji Michała Kleofasa Ogińskiego jest przechowywany jeden list biskupa do głównego adresata ${ }^{4}$.

Odnaleziona korespondencja pochodzi z lat 1792-1795. Dotyczy zatem okresu janowskiego, czyli najmniej rozpoznanego etapu życia autora Gtosu umartych. W listach do Kazimierza Naruszewicza czy Michała Kleofasa Ogińskiego podejmowany jest temat wyświadczania sobie wzajemnych przysług. W osobistym tonie został napisany list do króla. Nadawca użalał się w nim na przykre dla niego konsekwencje związane z prowadzonym rozwodem Kazimierza Nestora i Anny z Cetnerów Sapiehów.

Jednak przynajmniej z dwóch powodów najbardziej interesujące w tej grupie wydają się listy dotyczące prywatnych, gospodarskich zatrudnień biskupa. Mają one charakter osobisty. Werbalizują się w nich rozmaite stany emocjonalne Naruszewicza, co nie jest częstym zjawiskiem w biskupiej korespondencji. Jednocześnie to właśnie wyzwolenie emocji sprawia, że opis wydarzeń, dotyczący zwykłych czynności gospodarskich, staje się niezwykle ekspresyjny, zaś narracja przedstawionej historii niecnych postępków komisarzy i ekonomów, przez stopniowe odsłanianie prawdy, potęgujące stan silnego wzburzenia, nabiera dynamiki jak w dobrej powieści kryminalnej.

Ale listy Naruszewicza do Brochockiego i komisarza nie tylko pokazują prywatne, codzienne życie Adama Naruszewicza. Można dzięki nim dokonać sprostowań kilku nieścisłości, które wkradły się do Plattowego wydania korespondencji. Dają bowiem możliwość poprawnej rekonstrukcji pewnych wydarzeń... z beczką soli, zachudzoną krową i gorzałką w roli głównej. Początek tej historii to wrzesień 1792 roku.

Dwa lata wcześniej, w czerwcu 1790 roku, Stanisław August mianował Naruszewicza biskupem łuckim, choć nominację ze Stolicy Apostolskiej otrzymał dopiero 29 listopada. Od tego momentu autor Historii narodu polskiego stał się gospodarzem niezwykle rozległej diecezji, która w XVIII wieku obejmowała województwo wołyńskie, brzesko-litewskie, podlaskie i bracławskie, czyli dzisiejszy Wołyń, zachodnie Polesie oraz południowe i środkowe Podlasie. Sprawne prowadzenie tak dużych dóbr wymagało gospodarskich umiejętności, doskonałej organizacji, ale przede wszystkim znalezienia zaufanych ludzi, którym można powierzyć zarządzanie biskupimi włościami. Ta ostatnia kwestia okazała się najtrudniejsza, bowiem w ciągu kilku lat Naruszewicz niejednokrotnie zwalniał pracowników, niewłaściwie - lub częściej nieuczciwie - wywiązujących się z powierzonych obowiązków. Jedną z trudniejszych pod tym względem sytuacji poznajemy dzięki opublikowanej już korespondencji. Jednak dopiero w świetle nowo odnalezionych listów można odkryć właściwy przebieg wydarzeń.

Jej bohaterami byli nadawca listów, czyli Adam Naruszewicz, oraz adresaci: Antoni Brochocki, mąż Brygidy Mierzejewskiej, siostrzenicy biskupa, i komisarz łuckich dóbr, niejaki Mierzejewski.

W 1790 roku Naruszewicz osiadł w biskupiej rezydencji w Janowie Podlaskim. Jednak rozmaite obowiązki wzywały go często do stolicy. W tych ważnych dla kraju chwilach między 1790 a 1792 rokiem był zazwyczaj przy królu. Dozór nad dobrami biskupimi powierzył Antoniemu Brochockiemu, do którego miał bezgraniczne zaufanie. W liście z 27 lipca 1792 roku prosił go, by zarządzał łuckimi włościami, korzy-

${ }^{4}$ Za przekazanie informacji o liście składam serdeczne podziękowania dr Monice Myszor-Ciecieląg z Archiwum Zamku Królewskiego - Muzeum w Warszawie.

Sztuka Edycji 2/2018 
stając z wszelkich przywilejów władzy, jaką posiadał biskup: „[...] upraszam cię, mój Antoni, abyś w niebytności mojej zarządzał zupełnie całym gospodarstwem z tą władzą, którą ja tam mam, nie spuszczając się na dyspozycyje sług moich, których pod dozór W[ielmożnego] Pana poddaję i rozkazom, a dozorowi jego wszystkich poruczam"s.

Następna osoba, której Naruszewicz powierzył szerokie kompetencje, to Mierzejewski, komisarz dóbr. Wydaje się, że w ocenie biskupa także on był człowiekiem godnym zaufania. W cytowanym już liście prosił Brochockiego, by zechciał skonsultować się z komisarzem w sprawie zatrudnienia uczciwej osoby do prowadzenia poczty w Janowie. Wynika z tego, że Naruszewicz polegał na swoim głównym zarządcy. Niestety, jest to pierwsza i zarazem ostatnia pozytywna wzmianka na temat Mierzejewskiego.

Mając na uwadze opublikowaną przez Juliana Platta korespondencję, można zarzucić powyższemu stwierdzeniu osąd niezgodny z faktami. W wydaniu tym bez trudu można odnaleźć list pisany do Mierzejewskiego w grudniu 1792 roku, w którym nadawca z nieukrywaną sympatią, w poufałym tonie zwraca się z prośbą do komisarza o czuwanie nad następnymi etapami prac gospodarskich i kontrolowanie jakości płodów rolnych, narzekając jednocześnie na nieuczciwe praktyki nieznanego z nazwiska gubernatora, który pod nieobecność biskupa „charty i psy dla siebie chowa, jamy na wilki kopie, lisy bije i sam z tego pożytkuje"'.

Ton epistoły jest szczególnie zaskakujący w świetle odnalezionego listu Naruszewicza do tego samego adresata. Pod datą 30 września 1792 roku, a zatem w piśmie skreślonym blisko trzy miesiące wcześniej, Naruszewicz, pełen gniewu i oburzenia, zarzucał swojemu komisarzowi fałszerstwa, kradzieże i zaniedbania ${ }^{8}$. Wskazywał konkretne przykłady, wytykając m.in. oszustwa dotyczące sprzedaży soli. To jednak dopiero początek listy zarzutów wobec poczynań Mierzejewskiego. Naruszewicz, nie kryjąc żalu i złości, pisał: „Pochudziliście i pomorzyliście cielęta i mędaki najprzedniejsze. Z krów paktowych dwustu ledwo masła fasek 50 i syrów kiepskich, oślizłych kop tyleż. Masło najszkaradniejsze, pełne serwatki i plugastw, owszem drugie i z włoskami"'.

List utwierdza w przekonaniu, że biskup nie miał najmniejszych złudzeń co do działań swojego komisarza. Wiedział, że nie były jedynie wynikiem zaniedbań, lecz świadomych, zamierzonych kradzieży. Intencje Mierzejewskiego w tym zakresie stały się dla Naruszewicza aż nadto czytelne, gdy uzmysłowił sobie, że pan komisarz odwodził biskupa od zatrudnienia rachmistrza do kontroli ksiagg ${ }^{10}$. Gospodarz diecezji łuckiej nie omieszkał i tego wytknąć Mierzejewskiemu w liście. Żałował, że uległ tym namowom, lecz pod koniec września było już za późno na czynienie sobie wyrzutów. Należało podjąć zdecydowane kroki. Nieuczciwości Mierzejewskiego wyszły na jaw, dlatego Naruszewicz tonem nieznoszącym sprzeciwu pisał: „Musisz mi W[ielmożny] Panie nadgrodzić te szkody, któreś poczynił przez swój niedozór, zawodząc nadzieje moje i karmniąc tylko obietnicami”"11.

Wydaje się, że w całej tej sytuacji Naruszewicz miał trochę żalu do samego siebie, uświadamiając sobie, że zbyt łatwo zaufał Mierzejewskiemu i zbyt długo pozwolił omamiać się różnego rodzaju obietnicami komisarza. Jednocześnie, w trosce o swoje gospo-

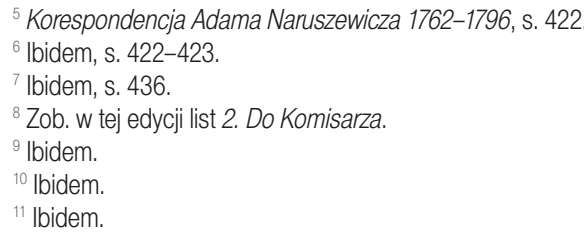


darstwo, przekazał nad nim pełną kontrolę Antoniemu Brochockiemu. „Daję zupełną moc memu siestrzeńcowi - pisał do komisarza - wejrzeć we wszystko i urządzić wszystko, a W[ielmożnemu] Panu go słuchać i pełnić jego dyspozycyje ode mnie podpisane, bo on ma moc zupełną, gdyby trzeba było i podziękować W[ielmożnym] Państwu za służbę nieużyteczną"12.

Listy skierowane do komisarza: pierwszy z września ${ }^{13}$ oraz drugi - prawdopodobnie z grudnia 1792 roku $^{14}$ - zdecydowanie różnią się tonem wypowiedzi. Jeszcze pod koniec lipca w liście do Brochockiego Naruszewicz pozytywnie wypowiadał się o swoim zarządcy ${ }^{15}$. We wrześniu skreślił do niego list pełen zarzutów o kradzieże i nieuczciwości. W grudniu zaś znów pisał do tego samego adresata w atmosferze zaufania i przyjaźni.

Sytuacja ta rodzi zasadnicze pytania. Skąd tak skrajna zmiana stosunku biskupa do komisarza? Co mogło mieć na to wpływ? I w końcu - czy dwa tak odmienne w tonie listy - wrześniowy i grudniowy - mogły być skierowane do tej samej osoby? I bynajmniej nie jest to koniec wątpliwości wynikających z tej korespondencji, gdyż jako osoba mająca pełnić kontrolę działań komisarza pojawia się zaufany siostrzeniec Naruszewicza. Kim zatem był siostrzeniec, a kim komisarz?

Dotychczas kwestia ta nie podlegała dyskusji. Julian Platt w przypisie do grudniowego listu, który według niego Naruszewicz skierował do Mierzejewskiego, informuje, że komisarz to syn Marianny Mierzejewskiej, koniuszyny nowogródzkiej, siostry Adama Naruszewicza. W objaśnieniu dodaje, że jest on prawdopodobnie tym zarządcą, który zwolnił się w kwietniu 1793 roku, co z kolei wynika z korespondencji z Brochockim ${ }^{16}$. Informacja o tożsamości komisarza prawdopodobnie trafiła do edycji gdańskiego badacza za pośrednictwem publikacji Edmunda Rabowicza ${ }^{17}$, który był pierwszym wydawcą tego listu. Platt odnotował informacje za Rabowiczem. Ten zaś, również nie wnikając w szczegóły, powołał się na Cezarego Dominika Chodźkę, który, jak domniemywał Rabowicz, otrzymał list od rodziny Mierzejewskiego ${ }^{18}$. Informacja na temat komisarza nie była więc przez żadnego z wydawców weryfikowana ${ }^{19}$.

W świetle objaśnień obu badaczy komisarz to siostrzeniec Naruszewicza. Potwierdzałaby to początkowa formuła epistolarna brzmiąca: „mój kochany siostrzanie"20. Lecz z nieopublikowanego listu takich prostych wniosków już wyciągnąć się nie da. Idąc bowiem za sugestiami Platta i Rabowicza, musielibyśmy uznać, że siostrzeniec i komisarz to ta sama osoba. Sytuacja co najmniej zdumiewająca, jednak wydaje się, że dzięki opublikowanej już oraz nowo odnalezionej korespondencji możliwa jest odpowiedź na pytanie: kto kradł sól i gorzałkę, a kto miał te niecne postępki powstrzymać.

Wiele wskazuje na to, że wydawców listów Naruszewicza zmylił, po pierwsze, zwrot do adresata „mój kochany siostrzanie” oraz, po drugie - nazwisko komisarza, które pada w liście do Antoniego Brochockiego z 7 lipca 1793 roku. Naruszewicz pisał w nim:

${ }^{14}$ Korespondencja Adama Naruszewicza 1762-1796, s. 435-437. List, o którym tu mowa, był według Juliana Platta skierowany do komisarza Mierzejewskiego.

${ }^{15}$ Korespondencja Adama Naruszewicza 1762-1796, s. 422.

${ }^{16}$ Ibidem, s. 437.

${ }^{17}$ E. Rabowicz, Inedita Naruszewicza, „Pamiętnik Literacki” 1958, nr 49, z. 3, s. 211-217.

${ }^{18}$ Ibidem, s. 213.

${ }^{19}$ Edmund Rabowicz nie tylko powielił niesprawdzone informacje, ale stworzył pewnego rodzaju kontekst sytuacyjny dla ich uzasadnienia, pisząc o Antonim Brochockim, nazywanym przez Naruszewicza siostrzeńcem: „U jego matki w Ostrówku (Nowogródzkie) gościł w lipcu 1775, a więc z górą przed 16 laty. Młodemu Mierzejewskiemu daje daleko idące pełnomocnictwa, zwierza się nawet z zamiaru usunięcia ekonoma"; ibidem.

${ }^{20}$ Korespondencja Adama Naruszewicza 1762-1796, s. 435
}

\section{Listy skierowane do komisarza: pierwszy \\ z września \\ oraz drugi - prawdopodobnie z grudnia 1792 roku - zdecydowanie różnią się tonem wypowiedzi}


„Potrzeba tak wymagała, abym się pozbył P[ana] K[omisarza] i niektórych ekonomów szkodliwych. Jakoż uprzedził jeszcze w aprylu myśli moje i onych się dorozumiał p. Mierzejewski, podziękowawszy mi listownie za służbę"21.

Tożsamość komisarza nie budziła więc u wydawców wątpliwości: siostrzeniec, mający na nazwisko Mierzejewski, mógł być tylko synem Marianny Mierzejewskiej. Wydawcy nie zwrócili uwagi na to, że Naruszewicz nazywał siostrzeńcem również Antoniego Brochockiego, męża Brygidy, siostrzenicy biskupa, córki Marianny. Zwrot ten obecny jest w przynajmniej dwóch listach. Adresatami pierwszego z nich, datowanego na wrzesień 1793 roku, byli Józef Piaskowski i Leon Sosnowski ${ }^{22}$. Drugi został napisany w sierpniu 1794 roku do Marianny Mierzejewskiejej. Naruszewicz tak zwracał się w nim do adresatów: „Moi ukochani, Siostro, Siestrzeńcze i Siestrzenico”, zaś z listu jednoznacznie wynika, że określenie „siostrzeniec” dotyczy Antoniego Brochockiego.

Niemniej jednak nie jest to argument zasadniczy, a jedynie wskazujący na konieczność dalszych rozpoznań. Ważne rozstrzygnięcia przynosi wgląd w drzewo genealogiczne biskupa. Naruszewicz miał cztery siostry ${ }^{24}$. Tylko jedna z nich, wspominana Marianna, wyszła za mąż za Mierzejewskiego. Państwo Mierzejewscy nie mieli jednak syna. Jedynym ich dzieckiem była córka Brygida, żona Brochockiego. Warto dodać, że Naruszewicz w całej swojej korespondencji nie wspomniał o innym - niż Brygida dziecku Marianny. Komisarz nie mógł więc być siostrzeńcem Naruszewicza. Istnieje prawdopodobieństwo, że był w jakiś sposób skoligacony z rodziną męża Marianny, lecz z pewnością nie był jej synem.

Wyjaśniałoby to zdumiewającą zmianę stosunku Naruszewicza do adresata listów. W świetle powyższych sprostowań należy bowiem przyjąć, że poufała epistoła z końca grudnia 1792 roku, którą Platt uznał za list do Mierzejewskiego, była adresowana w rzeczywistości do Antoniego Brochockiego, którego biskup nazywał siostrzeńcem. Siostrzeniec ów nie był jednak komisarzem dóbr, Mierzejewskim, jak zakładali Rabowicz i Platt.

Publikacja pism, z których aż sześć dotyczy „janowskiego” etapu życia Adama Naruszewicza, pozwala nie tylko dokonać pewnych sprostowań, ale również w jakimś stopniu dopełnia wizerunek Naruszewicza - biskupa i gospodarza.

Niemniej jednak - podobnie jak sześćdziesiąt lat temu Julian Platt - autorka edycji ma świadomość, że odnalezione listy nie zamykają prac nad korespondencją Adama Naruszewicza. Jest wręcz przeciwnie. Ich istnienie uzasadnia potrzebę kontynuacji poszukiwań i kwerend, które niezależnie od efektów stanowią nieodłączną część pracy każdego edytora.

\section{Zasady opracowania tekstu}

Interpunkcję zmodernizowano zgodnie ze współczesną normą. Starano się nie dzielić zdań wielokrotnie złożonych na zdania krótsze, szanując działania Naruszewicza w tym zakresie.

1 Ibidem, s. 448

2 Ibidem, s. 462.

${ }^{23}$ Ibidem, s. 479 .

${ }^{24}$ Barbarę, Mariannę i Ludwikę (z małżeństwa Jerzego Naruszewicza z Pauliną Abramowiczówną) oraz Helenę (z drugiego małżeństwa ojca z Elżbietą Narbuttówną). 
W podstawie wydania zachowano autorski układ akapitów.

Numeracja listów z informacją o adresacie pochodzi od wydawcy i została ujęta w nawias kwadratowy. Wprowadzono ją, by ułatwić przygotowanie odsyłaczy w przypisach.

Adresy odbiorców, jeśli takie zachowały się przy listach, zamieszczano na końcu pisma.

Rozwinięto wszystkie skróty, wskazując na zabieg zastosowaniem nawiasu kwadratowego.

Uporządkowano zapis majuskuł i minuskuł (np. Regestra $\rightarrow$ regestra, Krów $\rightarrow$ krów). Zachowano zasadę zapisu wielką literą tytułów grzecznościowych (np. Wielmożnego Pana).

Konsekwentnie uzupełniono znaki diakrytyczne.

Do współczesnej normy dostosowano pisownię łączną i rozdzielną (np. wstan $\rightarrow$ w stan).

Zgodnie z podstawą wydania łączną pisownię zastosowano w wyrazie niemasz (= łac. non est), kiedy występował w znaczeniu bezosobowym, tworząc z rzeczownikami (w dopełniaczu) zwroty wskazujące „brak” (kogo, czego), np. niemasz w Torczynie mego komisarza.

Zmodernizowano łączną pisownię wyrażeń w znaczeniu zaimkowym: potym $(=$ potem $) \rightarrow$ potem, zatym $\rightarrow$ zatem.

Formy sprzed przegłosu podano zgodnie z podstawą wydania: siestrzenec, siestrzenicę.

W transkrypcji samogłosek nosowych przyjęto zasadę modernizacji, np. aręda $\rightarrow$ arenda.

Głoski $i$ oraz $y$ oddano zgodnie ze współczesnymi regułami jako $i, y, j$. W wyrazach obcego pochodzenia zachowano wahania rękopisu w zakresie transkrypcji grup $-i j,-y j$ (np. dyspozycye $\rightarrow$ dyspozycyje, ale kompania).

Zmodernizowano końcówki narzędnika i miejscownika przymiotników i zaimków l.poj. r.m. i n. oraz l.mn.: -emi $\rightarrow-y m i$.

Dawną końcówkę $-q$ w bierniku l.poj. r.ż. zapisano bez zmian (np. obligacyja).

Bez zmian pozostawiono końcówkę - $a \mathrm{w}$ mianowniku l.mn. r.m. (np. regestra).

Zmodernizowano zapis głosek dźwięcznych i bezdźwięcznych $s$ i $z$ (np. bespieczeństwa $\rightarrow$ bezpieczeństwa, dyzpozycyi $\rightarrow$ dyspozycyi).

Bez modernizacji pozostał zapis grupy spółgłoskowej -śrz-, zgodnie z podstawą wydania (np. źrzódet).

Wprowadzono ks na miejsce łacińskiego $x$ (np. excerpcie $\rightarrow$ ekscerpcie).

Zlikwidowano geminaty (podwójne spółgłoski) w zapożyczeniach (np. masse $\rightarrow$ mase).

Zgodnie z podstawą edycji oddano zapis wyrazów bez nagłosowego $s$ (np. przedana), zachowując obecne w autografach wahania (np. przedana, przedat $\mid$ sprzedanego, sprzedany).

Zachowano konsekwentnie stosowaną przez Naruszewicza formę czasownika powinne (= powinno).

Utrzymano dawną postać rzeczowników: nadgrodzić, nadgrodzone.

Bez zmian zachowano dawne formy czasownikowe, np. odeśli (= odeślij), przyśli (= przyślij), uściśni (= uściśnij).

Wszystkie liczebniki zapisano zgodnie z podstawą wydania. 


\section{[1. DO STANISŁAWA AUGUSTA]}

Najjaśniejszy Królu, Panie mój Miłościwy,

list W[aszej] K[rólewskiej] M[ości] z najgłębszym odebrawszy respektem, mam honor rzetelną na pańskie wyrazy dać odpowiedź. Interes rozwodowy książąt Sapiehów, generalstwa artyleryi lit[ewskiej], tyle mi zadał trudności i przykrych doświadczeń, ile się wydarza temu, który - jak powiadają - między młotem a kowadłem jest położony. Od dwóch blisko lat będąc delegowanym sędzią, chciałem być zawsze przyjacielem razem stron obu i do pokoju nakłaniałem, ale gdy ten w interesach cywilnych za najwyższym nawet i najszacowniejszym W[aszej] K[rólewskiej] M[oś]ci jednaniem stanąć nie mógł, przyszło naprzód do kontynuacyi procesu separacyi, a potem za zgodą stron i do rozwodu.

Dekret mój separacyjny favere księżny generałowej ferowany na jakie mię w Warszawie i w Lublinie naraził nieukontentowania, wiadomo to publiczności. Teraz taż sama księżna generałowa żali się przed W[aszą K[rólewską] Mością na zwłoki ode mnie czynione. Trudno, Najjaśniejszy Panie, ludziom dogodzić, lecz trzeba dogodzić

Od dwóch blisko lat będąc delegowanym sędzią, chciałem być zawsze przyjacielem razem stron obu i do pokoju nakłaniałem sprawiedliwości.

Gdy stanęło między stronami, aby już przystąpić do rozwodu, a to się stało w mar$\mathrm{cu}$, należało mi potrójne pozwy posyłać do nieprzytomnego aktora, a to się musiało ciągnąć ze dwa miesiące. Nastąpiła w maju rozprawa. Prawo i sprawiedliwość każe słuchać indultów i replik, ferować dekreta akcesoryjne i tym się czasu zabrać musiało, ile w nieprzytomności czasem patronów, którzy będąc razem ludźmi i gospodarzami, wyjeżdżali czasem na wieś dla spraw rolniczych i rozrywki.

Ja sam, jak wiadomo W[aszej] K[rólewskiej] M[ości], tyląletnią, ciągłą i trudną pracą znużony, szukałem czasem rozproszenia trudów na wolniejszym powietrzu w tych mianowicie letnich skwarach, gdzie i biedna ptaszyna pod listeczkiem oddychać lubi.

W tych rzeczy okolicznościach i ciagu coż tu ma polityka, co sejmowe obrady, co mowa obrócona do króla, który w tych rozwodowych stron zachodach nieparcyjalny nigdy dla poddanych i obywatelów umysł ukazując, żądał tylko jedności i pokoju.

Przybędę ja w tych dniach, Miłościwy Panie, do Warszawy na usługi W[aszej] K[rólewskiej] M[ości] i Rady, a razem i na ukończenie tego pracowitego dla mnie rozwodu. Ale czyliż to mój dekret uczyni koniec wszystkiemu? Morze to wielkie do przebrnienia zostaje. Jeszcze metropolita, jeszcze Rzym pozostaje, a przysłowie niesie, że causae matrimoniales sunt causae immortales. Lepiej by zrobiła księżna generałowa, aby się pierwej za powodem ojca kreowanych przyjaciół ułożyła z mężem swoim w cywilności, bo bez tych kroków nigdy rzecz końca swojego nie weźmie. To jest moje zdanie, a razem zagruntowane na całe życie przedsięwzięcie, że jestem i będę do zgonu

Waszej Królewskiej Mości

Pana Mojego Miłościwego wierny poddany Adam Naruszewicz b[iskup] k[oadiutor] s[moleński]

Z Karniewka 16 Julii 1786

Autograf znajduje się w Archiwum Głównym Akt Dawnych w Warszawie, Zbiór Michała Marczaka, sygn. 3. 


\section{Objaśnienia}

3 książąt Sapiehów - chodziło o rozwód Kazimierza Nestora Sapiehy i Anny z Cetnerów

9 naprzód-najpierw

11 „favere" - (łac.) wsparcie

księżny generałowej - Anny z Cetnerów Sapieżyny

ferowany - (łac. fero - „niosę, noszę") zatwierdzony, zatwierdzający

12 nieukontentowania - niezadowolenia

16 stanęło - zostało ustalone

17 potrójne pozwy - wysyłane trzykrotnie

nieprzytomnego - nieobecnego

aktora - uczestnika wydarzeń; tu: Kazimierza Sapiehy

19 indultów - (łac. indultus - „pozwolenie”) zezwolenie władz duchownych na odstąpienie od przepisu kościelnego

ferować - (łac. fero - „niosę, noszę") zatwierdzać, orzekać

dekreta akcesoryine - tzw. akcesoria, czyli rozprawy wstępne

20 patronów - (łac. patronus - „obrońca, opiekun”) zastępców procesowych, adwokatów

26 nieparcyjalny - niestronniczy

29 Rady - Rada Nieustająca, czyli najwyższa władza administracyjna Rzeczypospolitej, powołana w 1775 roku przez sejm rozbiorowy

31 przebmienia - przebrnięcia, przebycia

32 "causae matrimoniales sunt causae immortals” - (łac.) „sprawy małżeńskie [= sądowe sprawy dotyczące małżeństwa/ /rozwodów] są wieczne [= nigdy się nie kończa]"; nie udało się odnaleźć takiego przysłowia. Naruszewicz prawdopodobnie użył słowa „przysłowie” dla podkreślenia powszechności pewnych twierdzeń i w tym kontekście ma ono znaczenie „jak się powiada, jak się mówi”. Za sugestie dotyczące przekładu dziękuję pani Ariadnie Masłowskiej-Nowak.

33

pierwej- najpierw

ojca - Ignacy Aleksander Cetner (1728-1800), marszałek wielki koronny Królestwa Galicji i Lodomerii (od 1783 roku)

40

„Julii" - (łac.) lipiec

\section{[2. DO KOMISARZA]}

[Jego]m[oś]ci Panie Komisarzu,

pojedziesz W[ielmożny] Pan z moim siestrzeńcem do Torczyna dla podania porządnego w jego dzierżawę tych folwarków. Ta moja determinacyja niech będzie ostrzeżeniem dla moich sług ekonomicznych w Janowie, abym wkrótce, sprzykrzywszy sobie ich niedbalstwo, nie podziękował im za usługi.

O jakże te regestra mylne i fałszywe! Wszystko razem pomieszano i jeszcze do ś[więtego] Michała nieskończone, choć przed ś[więtym] Janem być powinne.

Zasiewy jarzyn najnikczemniejsze! W percepcie pieniężnej janowskiej pod tytułem arendy stawskiej wścibiona inną ręką sól przedana jakoby 26 beczek po złotych 16 . A przecież w rejestrze solnym Kobylińskiego, ręką jego pisanym, który jest między papierami oddanymi dla obrachunku soli panu szambelanowi, napisał wyrá́nie 
Kobyliński, że tylko osiem beczek soli stawskiej przedano po złotych 16, a reszta po 18. Któż pisze pod arendą sól i miesza jedno z drugim? Ponawiam rozkaz mój, aby Kobyliński udzielny zrobił obrachunek tej soli: gdzie, komu i za co przedał, gdzie

15 pieniądze obrócił. Z tej soli beczek 22 w Karniewku zostało się. Kazałem zawieźć do Skrzeszewa beczek 12, więc i te 12 do rachunku beczek 500 wchodzić powinne.

A o pakcie co mam pisać i oborze? Pochudziliście i pomorzyliście cielęta i mendaki najprzedniejsze. Z krów paktowych 200 ledwo masła fasek 50 i syrów kiepskich, oślizłych kop tyleż. Masło najszkaradniejsze, pełne serwatki i plugastw, owszem dru-

20 gie i z włoskami. Musisz mi W[ielmożny] Pan nadgrodzić te szkody, któreś poczynił przez swój niedozór, zawodząc nadzieje moje i karmniąc tylko obietnicami i odwodząc mię jak na zdradę, abym nie chował rachmistrza, który by wejrzał w służbę samego W[ielmożnego] Pana.

Życzę W[ielmożnemu] Panu otrząść się z tego snu i dzielniej pełnić powinności

25 swoje. Kiedy z łaski mojej do kilkunastu osób swoich tak wygodnie żywisz, kiedy tyle bydła i koni chowasz, a mnie zamiast pomnażania intraty płonnym językiem obiecywanej, tyle szkody czyniąc dopuściłeś.

Daję zupełną moc memu siestrzeńcowi wejrzeć we wszystko i urządzić wszystko,

Żal mi pracy mojej, żem tyle nagadał, tyle napisał przez rok, a słowa moje na wiatr poszły a W[ielmożnemu] Panu go słuchać i pełnić jego dyspozycyje ode mnie podpisane, bo on ma moc zupełną, gdyby trzeba było i podziękować W[ielmożnemu] Państwu za służbę nieużyteczną.

Żal mi pracy mojej, żem tyle nagadał, tyle napisał przez rok, a słowa moje na wiatr poszły. Tyle ludzi, tyle sług, tyle subalternów, a dozoru i głowy niemasz. Może W[ielmożny] Pan byłeś dobry ekonom, ale zły komisarz. Z domu W[ielmożnego]

35 Pana nie widać w polu, wygody lubisz udzielne, folwarków nie odwiedzasz. Ten też Kobyliński, podobny W[ielmożnemu] Panu gubernator, niech się strzeże mojego gniewu!

307 bri 1792

Autograf znajduje się w Archiwum Głównym Akt Dawnych w Warszawie, Zbiór Muzeum Narodowego, sygn. 1065.

\section{Objaśnienia}

1 Komisarzu - ostatecznie nie ustalono tożsamości tej osoby

2 siestrzeńcem - siostrzeńcem; tu: Antoni Brochocki († 1806), poseł na sejmy, szambelan Stanisława Augusta, kawaler Orderu Świętego Stanisława (1791). Jego drugą żoną (od 1788 roku) była siostrzenica Adama Naruszewicza, Brygida Mierzejewska, córka Marianny z Naruszewiczów i Jerzego Mierzejewskich. Z tego względu Naruszewicz często nazywa Brochockiego siostrzeńcem.

do Torczyna - w XVIII wieku miasteczko położone w województwie wołyńskim (dziś: osiedle typu miejskiego w obwodzie wołyńskim na Ukrainie)

$4 \quad$ w Janowie - Janów Podlaski, w XVIII wieku miasto będące siedzibą biskupów łuckich (dziś: wieś w województwie lubelskim)

sprzykrzywszy - znudziwszy się, zmęczywszy

6-7 do ś[więtego] Michała - wspomnienie św. Michała Archanioła przypadało 29 września

7 przed ś[więtym] Janem - wspomnienie św. Jana Chrzciciela przypadało 24 czerwca

8 najnikczemniejsze - najgorsze 


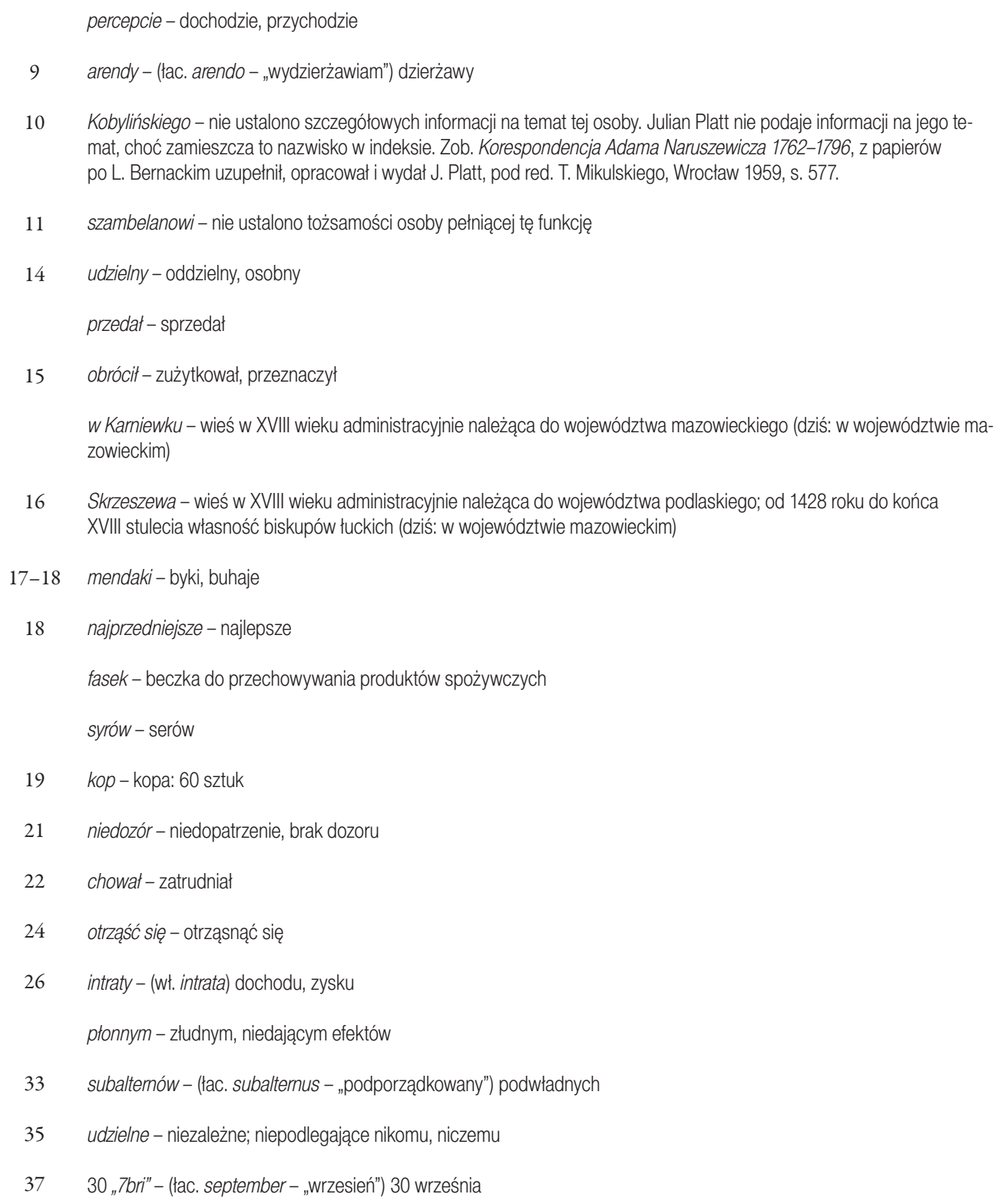

16 Skrzeszewa - wieś w XVIII wieku administracyjnie należąca do województwa podlaskiego; od 1428 roku do końca XVIII stulecia własność biskupów łuckich (dziś: w województwie mazowieckim)

17-18 mendaki-byki, buhaje

18 najprzedniejsze - najlepsze

fasek - beczka do przechowywania produktów spożywczych

syrów - serów

19 kop-kopa: 60 sztuk

21 niedozór - niedopatrzenie, brak dozoru

22 chowat-zatrudniał

24 otrząść się - otrząsnąć się

26 intraty - (wł. intrata) dochodu, zysku

płonnym - złudnym, niedającym efektów

33 subalternów - (łac. subalternus - „podporządkowany”) podwładnych

35 udzielne - niezależne; niepodlegające nikomu, niczemu

3730 „7bri” - (łac. september - „wrzesień”) 30 września

\section{[3. DO ANTONIEGO BROCHOCKIEGO]}

\section{9bris 1792}

Dziękuję Ci, mój kochany Antosiu, za staranie o moje rzeczy w Torczynie i spodziewam się, że przez Twoję pilność skrzywdzonym nie będę od tych, którzy dobrze płatni i karmieni służyć mi dobrze powinni byli.

O słodzie i żelazie remanentowym, że go zostawiam do dyspozycyi W[ielmożnego]

Pana i na jego początkowe potrzeby, już we dwu listach poprzedniczych pisałem.

Pisałem też i o tym, że żadnych asygnacyi na wręby do lasów i na polowania nie dam, bo chcę mieć lasy ani puste, ani spustoszone.

Dziwno mi, że dotąd niemasz w Torczynie mego komisarza, który już z Janowa od dwóch tygodni wyjechał. Wejrzyj z nim pilnie we wszystko, a mianowicie w krescencyją i słody przyszłoroczne tak z domowego jęczmienia, jako też i kupnego. 
W rachunkach pisarza łuckiego widzę w percepcie słodu korcy 341, g[arnców] 14. $\mathrm{Z}$ tego przedano na rzecz moją $\mathrm{k}$ [orcy] $94 \mathrm{i}$ to kiepsko, ponieważ ja sam płaciłem po zł[otych] 5 . A w ekscerpcie z rejestrów gubernatorskich przysłanym mi widzę tam

15 znowu kilka artykułów, że ten łucki 17 aug[usta] przedał Żydom k[orcy] 13, a \# 5. A do Zaborola korcy 24, a \# 6. Także Żydom (bez daty, miesiąca i dnia) korcy 8, a \# 5. J[ego] $\mathrm{m}$ [ó́] ć za słodu piwnego sprzedanego k[orcy] 15, a \# 6 .

Trzeba zatem wyegzaminować naprzód masę całą jęczmienia krescencyjnego i kupnego, a potem tę masę podług ryczałtu dzielić na wyrobek, krup, na ordynaryją, na piwo dubeltowe, na słód sprzedany. Rozum Twój i pilność wyświeci wszystkie błędy, które mi nadgrodzone być powinne po kalkulacyji ścisłej.

Myśli i spekulacyje moje względem gorzałki posyłam na udzielnym papierze, które spodziewam się, że nie będą odrzucone. Gorzałka tu dotąd nie płaci, bo tylko dają po zł[otych] 3 i pół. Może potem cena podrośnie.

25 Tyle naczyń kazałem narobić do browaru, więc dasz radę, aby gorzałka moja, którą do Janowa prowadzić będę, mogła być w miejscu naczynia przetoczona dla łatwiejszego rozdziału ciężaru na konie.

Pieniądze remanentowe ze wszystkich źrzódeł poodbieraj i z nich naprzód dług Żyda

Rozum Twój i pilność wyświeci wszystkie błędy, które mi nadgrodzone być powinne po kalkulacyji ścisłej 100 \# z procencyją oddaj, a co się zostanie, to mi przywieziesz do Janowa, gdzie i ja będę na święta.

Względem podwodu trzeba nam się porozumieć, abym ja, gdy będziesz czego potrzebował z Janowa, dawał do Torczyna podwody janowskie i wzajemnie, abyś posyłał podwody torczyńskie.

Teraz rad bym, abyś mi przysłał armatek cztery i moździerzy siedem oraz stolik marmurowy do Janowa.

Ponieważ p[aństwo] kasztelaństwo mają być w Dubnie na kontrakty, więc, mój Antosiu, opatrz gdzie parę izbinek dla nich.

Bawolicę każ doić na śmietankę dla matki, żony i córki swojej. Mam ja jeszcze na Ukrainie bawołów czy bawolic 4 i bydła sztuk ze 30, którego teraz dla rozruchów sprowadzić nie mogłem do Janowa. Więc to wszystko na wiosnę sprowadzę, abym miał oborę i bawolnią pomnożone.

Niech Bóg nie pamięta temu Kostkiewiczowi, który nie dopilnował tylu szkód i ciężarów przez podanie komisyi na mię włożonych. Trudno już temu zabieżeć w tych kłótliwych czasach, gdzie jesteśmy bez żadnego rządu.

Ściskam Cię serdecznie oraz siostrę, siestrzenicę i wnuczki moje z serca życzliwy

$\mathrm{A}[\mathrm{dam}] \mathrm{N}$ [aruszewicz] b[iskup] H[ucki]

Skóry wszystkie remanentowe tak z Torczyna, jak z Boratyna odeśli do Janowa.

Jeśli Żydzi ołyccy wzięli już tę gorzałkę pocztą, uczyń tak, jak mi projekt podałeś. Każ tyle ze swojej przelutrować, ile moja prostka by wydała według tabeli, a w czasie litrowaną sprowadzę do Janowa.

Będę też umiał być względnym za przysługi mi uczynione.

Autograf znajduje się w Archiwum Głównym Akt Dawnych w Warszawie, Zbiór Muzeum Narodowego, sygn. 64. 


\section{Magdalena Bober-Jankowska}

\section{Objaśnienia}

„9bris" - (łac. november - „listopad”) 9 listopada

2 kochany Antosiu - Antoni Brochocki. Zob. objaśnienie do w. 2 w liście 1. Do Komisarza.

w Torczynie - zob. objaśnienie do w. 2 w liście 2. Do Komisarza

5 słodzie - kiełkujące ziarna zbóż (najczęściej jęczmienia); surowiec używany w piwowarstwie

żelazie remanentowym - (z łac.) zapasowym, pozostającym w zapasach

6 poprzedniczych - poprzedni, uprzedni. Znany jest jedynie list do Antoniego Brochockiego z 27 sierpnia 1792 roku. Zob. Korespondencja Adama Naruszewicza 1762-1796, z papierów po L. Bernackim uzupełnił, opracował i wydał J. Platt, pod red. T. Mikulskiego, Wrocław 1959, s. 421-424.

7 asygnacyi - (łac. assignarei - „naznaczyć komu, przydzielać”) przeznaczenie na coś określonej sumy

wręby - prawo wyrębu drzew w lesie

$9 \quad$ niemasz - nie ma

komisarza - ostatecznie nie ustalono nazwiska komisarza, o którym mowa w tym liście

z Janowa - zob. objaśnienie do w. 4 w liście 2. Do Komisarza

10 krescencyją - (łac. crescentia - „wzrost, urodzaj”) plony rolne, zbiory

12 pisarza łuckiego - prawdopodobnie Franciszka Fortunata Rohozińskiego (XVIII), podkomorzego krzemienieckiego (1794-1795), pisarza ziemskiego łuckiego (1781-1794), kawalera Orderu Świętego Stanisława (1791)

percepcie - (łac. perceptum) dochód, przychód

korcy - (korzec) w Polsce do XIX wieku jednostka objętości ciał sypkich. Zawierała trzydzieści dwa garnce.

g[arnców] - dawna polska miara objętości cieczy i ciał sypkich. Zawierała cztery kwarty.

13 przedano - sprzedano

14 ekscerpcie - (łac. excerptio - „urywanie, robienie wypisów”) pisemny wyciag z dokumentu

15 ten łucki - pisarz ziemski łucki, Franciszek Fortunat Rohoziński

aug[usta] - (łac. augustus - „czcigodny; nazwa miesiąca ustanowiona w starożytnym Rzymie na cześć cezara Augusta”) sierpień

$\#-$ złotych

15-16 do Zaborola - w XVIII wieku wieś w województwie wołyńskim, położona ok. 7 km na zachód od Łucka (dziś: na Ukrainie w obwodzie wołyńskim)

18 wyegzaminować - (łac. examen - „badanie, próba”) zbadać, wybadać

naprzód - najpierw, w pierwszej kolejności

19 wyrobek - wyrabianie, wyrób

krup - oczyszczone ziarno kaszy jęczmiennej

ordynaryją - (łac. ordinarius - „zwyczajny”) część zarobków oficjalistów dworskich wypłacana w naturze (np. w zbożu, ziemniakach)

20 wyświeci-wypędzi, usunie

21 nadgrodzone- nagrodzone

22 udzielnym - zob. objaśnienie do w. 14 w liście 2. Do komisarza

23 nie płaci-jest mało dochodowy, nieopłacalny 
Spodziewam się, że cała ta moja gorzałka zabrana będzie i przywieziona do Janowa. Sanna teraz dobra, a zatem i przewóz takowy będzie

41 prowadzić - sprowadzać

źrzódeł - źródeł

procencyją - oprocentowaniem

podwodu - konny środek transportu z obsługą

p[aństwo] kasztelaństwo - Anna z Dąbskich i Dionizy Mniewscy, kasztelaństwo brzeskokujawscy

Dubnie - (Dubno) miasto na Wyżynie Wołyńskiej w XVIII wieku administracyjnie należące do województwa wołyńskiego (dziś: na Ukrainie, w obwodzie rówieńskim). Kontrakty w Dubnie odbywały się w latach 1774-1794.

kontrakty - (łac. contractus) systematycznie odbywające się zjazdy w miejscu wskazanym dla danej prowincji, podczas których załatwiano sprawy majątkowe, handlowe itd.

matki - matką Antoniego Brochockiego była Domicela z Cieńskich

żony - żoną Antoniego Brochockiego była Brygida z Mierzejewskich

córki - córką Antoniego Brochockiego ze związku z Barbarą Mierzejewską była Barbara Brochocka

dla rozruchów - Naruszewicz ma zapewne na myśli wojnę w obronie Konstytucji 3 maja między Polską a Rosją

- Adam Naruszewicz nazywał wnuczkami córki Antoniego Brochockiego, prawdopodobnie mając na myśli córkę z pierwszego małżeństwa z Józefą z Walewskich, Teresę Brochocka, oraz Barbare, córkę Brygidy z Mierzejewskich

51 przelutrować - (niem. läutern ) oczyścić

prostka - rodzaj niedrogiej wódki

względnym - mającym coś na uwadze

\section{[4. DO ANTONIEGO BROCHOCKIEGO]}

Z Janowa 179312 Januarius

Mój kochany Antosiu,

posyłam po gorzałkę podwód 20, do których kiedy przydasz tyleż torczyńskich, a J[egomość] ks[iądz] Maniecki przyda z Sadowa co będzie trzeba i o co go w liście

5 moim proszę. Spodziewam się, że cała ta moja gorzałka zabrana będzie i przywieziona do Janowa. Sanna teraz dobra, a zatem i przewóz takowy będzie. Możesz dla straży przydać dwóch szlachty czynszowych, bo to towar potrzebuje pilności.

Jeżeli ten mój list przyjdzie wcześnie i zastanie jeszcze J[aśnie] W[ielmożnego] kasztelana, pokłoń ode mnie serdecznie, także uściśni serdecznie ukochane moje siostrę,

10 siestrzenicę i wnuczki. 
Jeśli będzie można, przyśli mi armatki i moździerzyki.

Mój kochany p[anie] Antoni. Jeślibyś potrzebował naczyń mniejszych, obliguj ks[iędza] Manieckiego, żeby pożyczył, a ja odeślę mu nazad. P[an] porucznik za kilka dni pojedzie do Was na polowanie.

Jestem kochający Was i sługa

[adres:] Wielmożnemu J[ego]m[oś]ci Panu Antoniemu Brochockiemu, szambelanowi J[ego] K[rólewskiej] M[ości], a mojemu kochanemu siestrzeńcowi w Torczynie.

Autograf znajduje się w Archiwum Głównym Akt Dawnych w Warszawie, Zbiór Muzeum Narodowego, sygn. 64.

\section{Objaśnienia}

$1 \quad$ z Janowa - zob. objaśnienie do w. 4 w liście 2. Do Komisarza

12 „Januarius” - 12 stycznia 1793 roku

4 Maniecki - nie ustalono szczegółów dotyczących tej osoby. Julian Platt nie podaje informacji na jego temat, choć zamieszcza to nazwisko w indeksie. Zob. Korespondencja Adama Naruszewicza 1762-1796, z papierów po L. Bernackim uzupełnit, opracował i wydał J. Platt, pod red. T. Mikulskiego, Wrocław 1959, s. 580. Wiadomo jedynie, że to duchowny katolicki, proboszcz w Sadowie.

z Sadowa - (Sadów) w XVIII wieku wieś należąca administracyjnie do województwa wołyńskiego, położona niedaleko Łucka, należąca do biskupstwa łuckiego

$9 \quad$ kasztelana - Dionizego Mniewskiego

siostrę - zob. objaśnienie do w. 45 w liście 3. Do Antoniego Brochockiego

10 siestrzenicę - zob. objaśnienie do w. 46 w liście 3. Do Antoniego Brochockiego

wnuczki - zob. objaśnienie do w. 46 w liście 3. Do Antoniego Brochockiego

13

nazad - z powrotem

porucznik - nie ustalono tożsamości tej osoby

18 w Torczynie - zob. objaśnienie do w. 2 w liście 2. Do Komisarza

\section{[5. DO KAZIMIERZA NARUSZEWICZA]}

Jaśnie Wielmożny [Jego]m[oś]ci Dobrodzieju, jeśli związki przyjaźni, pokrewieństwa i wzajemność usług są dla mego kochanego kuzyna powodem do wysłuchania próśb moich, obliguję J[aśnie] W[ielmożnego] W[ielmożnego] P [ana] D[obrodzieja] na to wszystko, ażebyś raczył dopomóc w asesoryi W[ielkiego] Ks[ięstwa] L[itewskiego] w sprawach W[ielmożnego] J [aśnie] P[ana]

Przeńskiego, starosty niedzialskiego, które się w sądzie toczyć będą. Żyję z J [aśnie] $\mathrm{P}[\mathrm{anem}]$ starostą $\mathrm{w}$ niewzerwanej przyjaźni od lat blisko trzydziestu, a jego też spowinowacenie z domem Ogińskich, do obu nas nalegącym, i pamięć też na to, że to starostwo posiada po niegdyś imienniku moim, a krewnym J[aśnie] W[ielmożnego] Pana, są także powodem do interesowania się za nim. Racz przyjąć tę obligacyją, mój kuzynie, od tego, 
który jest ze statecznym przywiązaniem i należytym szacunkiem Jaśnie Wielmożnego Dobrodzieja z serca życzliwym bratem i najniższym sługą

Adam Naruszewicz, b[iskup] ł[ucki]

Z Warszawy 5 kwietnia, 1793

Autograf znajduje się w Archiwum Głównym Akt Dawnych w Warszawie, Zbiór Muzeum Narodowego, sygn. 1065.

\section{Objaśnienia}

3 kuzyna - Kazimierza Naruszewicza (1730-1809), stryja Adama Naruszewicza, rektora Collegium Nobilium w Wilnie (od 1769 roku), scholastyka smoleńskiego (od 1776 roku)

obliguje - (łac. obligo - „obligować”) usilnie prosić

6 Przeńskiego - nie ustalono bliższych informacji na temat tej osoby. Nie odnotowuje jej również Julian Platt.

7 niewzerwanej- nierozerwalnej

8 Ogińskich - ród książęcy pochodzenia ruskiego. Nie udało się odnaleźć koligacji tego rodu z Przeńskimi. nalegącym - tu: właściwym, wspólnym dla nadawcy i odbiorcy

9 imienniku moim - nie ustalono, który z Naruszewiczów był starostą niedzialskim

10 interesowania się za nim - sens: interesowania się nim, wstawieniem się za nim obligacyją - (łac. obligatio) zobowiązanie, powinność

\section{[6. DO MICHAŁA KLEOFASA OGIŃSKIEGO]}

Jaśnie Wielmożny m[oś]ci Dobrodzieju, chętnie się przychylam do zaszłych mi rozkazów J[aśnie] W[ielmożnego] P[ana] Dobrodzieja i żądany indult dla osób mających wstąpić w stan małżeński natychmiast posyłam. Niech Pan będzie pewny, że jak z duszy i serca do jego samej osoby oraz do

5 całej jego familii, do której mam honor należeć, przywiązany jestem, tak wszelkie jego skinienia dopełniać najmilszym dla mnie będzie i jest obowiązkiem. Jestem z wysokim respektem i uprzejmym przywiązaniem.

Jaśnie Wielmożnego P[ana] Dobrodzieja mego kochanego z serca życzliwy i najniższy sługa

Autograf znajduje się w Archiwum Zamku Królewskiego w Warszawie - Muzeum, sygn. D II. 


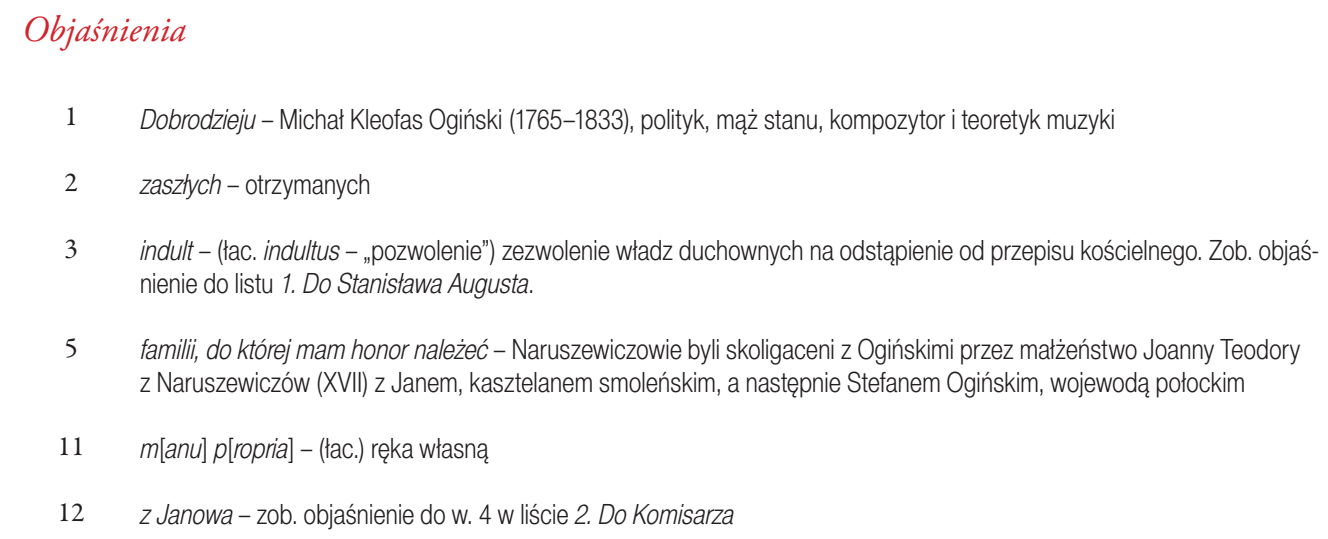

\section{[7. DO ANTONIEGO BROCHOCKIEGO]}

Doznawszy najprzykrzejszych losów w kordonie pruskim J[aśnie] W[ielmożna] kasztelanowa brzeska kujawska z przyczyny rewolucyi, zaboru majątku i oddalenia się w obcy kraj męża, jedzie teraz do Krasnorosyi dla ocalenia ile być może dóbr tamecznych. Przyjąłem ją w domu jak należy na jej urodzenie, poczciwość i najwyborniejsze przymioty. Gdy jej trakt wypada na Torczyn, ufam Wam siostro i siestrzeńcy moi, że ją tam, $\mathrm{w}$ równych moim sentymentach przyjąwszy i dawszy słodki spoczynek, wyprawicie w dalszą podróż, owszem na miejsce z najlepszą wygodą. Co będzie potrzeba, da ustną interpretacyją p[an] Mikołaj, którego dla kompanii i bezpieczeństwa aż na miejsce posyłam.

Cokolwiek dla tej zacnej pani uczynicie, uczynicie dla mnie, bo mię los jej bardzo dotyka. Ja się tu w Janowie was spodziewam i gotuję dom z otwartym sercem. Bywajcie zdrowi.

\section{Z Janowa 179520 8bris}

[adres:] Monsieur Antoine Brochocki chambelan du Roi de Pologne et mon cher neveu w Torczynie. W jego niebytność otworzy ten list siostra moja.

Autograf znajduje się w Archiwum Głównym Akt Dawnych w Warszawie, Zbiór Muzeum Narodowego, sygn. 64.

\section{Objaśnienia}

\footnotetext{
1-2 kasztelanowa brzeska kujawska - Anna z Dąbskich Mniewska

2-3 w obcy kraj męża - mężem Anny z Dąbskich był Dionizy Mniewski. Zob. objaśnienie do w. 36 w liście 3. Do Antoniego Brochockiego. W latach 1795-1796 był przewodniczącym Deputacji Polskiej w Paryżu, prawdopodobnie dlatego przebywał poza granicami kraju.

5 siostro - zob. objaśnienie do w. 45 w liście 3. Do Antoniego Brochockiego

siestrzeńcy - siostrzeńcy; tu: prawdopodobnie synowie Antoniego Brochockiego: Józef (z małżeństwa z Józefą Walewską) oraz Adam (z małżeństwa z Brygidą Mierzejewską)

$8 p[a n]$ Mikołaj - nie ustalono tożsamości tej osoby

11 Janowie - zob. objaśnienie do w. 4 w liście 2. Do Komisarza
}

\section{Cokolwiek} dla tej zacnej pani uczynicie, uczynicie dla mnie, bo mię los jej bardzo dotyka 
„chambelan du Roi de Pologne et mon cher neveu” - (franc.) „Szambelan króla Polski i mój drogi siostrzeniec”

w Torczynie - zob. objaśnienie do w. 2 w liście 2. Do Komisarza

Key Words: Adam Naruszewicz, Antoni Brochocki, Mierzejewski, Janów Podlaski, correspondence

Abstract: The article contains editions of seven unknown, so far unpublished, letters by Adam Naruszewicz. As many as six of them were written in years 1792-1793, which is the period when Naruszewicz was permanently staying at the home of Łuck bishops - Janów Podlaski. It is the least thoroughly investigated period of the bishop's life. The published correspondence mostly concerns managing the bishop's estate and the problems related to it. However, the motifs concerning particular individuals have also allowed for making a number of biographical clarifications related to the closest family of Adam Naruszewicz. 